catheter is manufactured solid from the second perforation to the point of the beak. Daily friction with this form of stilette and constant immersion in some antiseptic solution will prove of great value with all instruments in constant use. . Catheters of this description can be obtained of Messrs. Maw, Son, and Thompson, of London.

\section{TREATMENT OF HYPERIDROSIS.}

W. P., M.B., writes : In reply to “"Surgeon-Lieutenant-Colonel," I beg to suggest that the cause is atony of the vasomotor nexves, and to

TOTES, HETHERS, Ete.

Correctron.

THF chart published on p. 1294 to illustrate Dr. John Gordon's paper on piperazine should have been described as being designed to illustrate
the action of 1.25 per cent., 2.5 per cent., and 5 per cent. solution of the action of 1.25 per cent
piperazine on uric acid.

ANSELL V. TAIT FÜD.

DR. G. T. KeELE, Treasurer (81, St. Paul's Road, Highbury), desires to acknowledge the following subscriptions received for this fund:

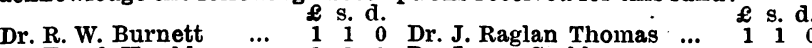

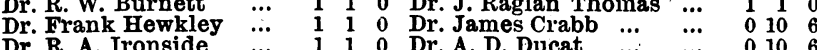

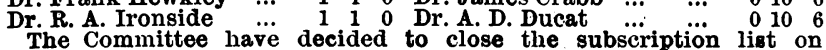
June 26th.

A SURVIVOR OF THE GRANDE ARMÉE.

THE St. Petersburger medicinische Wochenschrift states that in the town of Bsaratoff there is now living a man who on April 24 ' 1 celebrated his 126th birthdas. He is a Frenchman, named Nicolas sivin, who was a lieutenant in the Grande Armé in the Russian campaign of 1812, and who was taken prisoner at the crossing of the Beresina. Being imwho was taken prisoner at the crossing of the Beresina. Being imprisoned at Ssaratoff he has never cared to leave it, but has remained ably vigorous considering his patriarchal age.

Cancer and Vaccination.

Ix these latter days we have heard of cancer being ascribed to tomatoes, hypophosphites, pork, monogamy, and many equally improbable causes. A writer in a recent number of the Weekly Dispatch now alleges that it is due to vaccination. The cancor mortality has increased, he thinks, because vaccination has been made compulsory. This reasoning is in strict accord with the good old rule of post hoc, ergo propter hoc, than which the writer can adduce no more conclusive argument. AIRTHREY MINERAL WELLS.

DR. PATERson (Fernfield, Bridge of Allan) writes as follows about the Airthrey mineral waters: After fifty years' experience and study of the therapeutic action of the waters, I am in a position to say that $I$ have found them almost unsurpassed as a remedy for dyspepsia, habitual constipation, certain liver and kidney complaints, as also rheumatism constipation, certain liver and kidney complaints, as also rheumatism Bridge of Allan waters and baths after those of Buxton and Bath had each been tried without beneficial result. As a rule they ought to be each been tried without beneficial result. As a rule they ought to tried for fourteen days to one month, and in some cases even a longer time than this might be necessary. The water ought to be taken every morning before breakfast, the patient going personally to the well house, not having the water brought to him as is too olten the case. This courge should be aided by a bath taken every second or third days quantity of water should be gradually diminished, so that at the end of effect.

Before beginning a course it is very necessary that the intending water drinker should consult a properly qualified medical practitioner, as it is a very essential part of the treatment that the system should be prepared beforehand to accept as well as possible the full benefit of the
waters. The action is in the first instance an aperient one, then diuretic, alterative, and tonic, and, after the course is once properly gone through, does not-as is sometimes the case with other watersnecessitate a continuance more or less long of some other laxative medicine. After my long experience, I have come to the conclusion that there is no better saline mineral water in the world than this of Bridge of Allan, and I thoroughly believe that I owe my long life and good health to the judicious use of this water. In the truest sense it is a product of Nature's own laboratory.

LONG RETENTION OF HALFPENNY IN STOMACH.

MR. OSWALd F. RowLEY, M.R.C.S.Eng., L.R.C.P.Lond. (Barnsley), writes Some time ago I was called to see J. M., aged 10 years, who was reported to have swallowed a halfpenny. The parents were much more alarmed than the patient, who seemed to suffer but little from what she had done. Emetics were freely administered without causing the expulsion of the foreign body. The usual dietary was then prescribed, and the motions carefully watched. By lapse of time this was neglected and the coin was supposed to have been passed. Six months afterwards the child was seen to vomit a substance coated with mucus, which on examiuation turned out to be the missing halfpenny. It is a curious fact that, though the copper was retained in the child's stomach for so long a period as six months, none of the symptoms of copper poisoning appeared.

LETTERS, COMMUNICATIONS, ETc., have been received from :

(A) Mr. T. Allen, Dudley; Mr. T. E. Akeson, Chester; Dr. J. T. Arlidge, Newcastle-under-Lyme; Mr. A. H. Allen, Sheffield ; Dr. C. H. Alfrey, St. Leonard's-on-Sea. (B) Mrs. Brock, Blackpool; Mr. J. W. Baker, Derby; Dr. K. A. Bahadh urï, Bombay; Dr. D. C. Black, Glasgow ; Mr. J. P. Bush, Clifton; Mr. R. J. Bryden, Gravesend Mr. H. L.
Browne, West Bromwich ; J. I. H. Browne, M.B., Coventry. (C) Mr. L. J. G. Carré, London; Chelsea Hospital for Women, Secretary, London ; Dr. M. Copeman, London; Mr. H. Cuthbertson, Aberdeen ; Dr. W. A. Carline, Lincoln ; Caution; Mr. H. Cooper, Salford; Lady Clark, Essendon. (D) The Derbyshire Royal Infirmary, Secretary, Derby ; Mr. W. Dalton, Blackpool; Mr. A. J. De Butts, Folkestone Mr. J. Davison, Abberley; W. F. R. De Watteville, M.B., Kingussie Mr. H. P. Dunn, London; Dr. H. M. Duncan, London. (ज) Mr. J. Ewart, Brighton; Mr. G. Edgar, London; Dr. C. R. Elgood, Battle E. H H.; Mr. J. A. Eyton-Jones, Wrexham, (J) Dr. T. Fisher, Clifton. F. S. (G) Mr. S. Garcill, London ; Gresham Life Assurance Company, Secretary, London; Mr. C. W. Glassington, London; Dr. A. H. Goslett, New York; Dr. A. C. Godfrey, Southampton ; Dr. H. R. Greene, Knaphill. (E) Dr. W. Hardman, Blackpool ; Mr. W. F. Haslam, Birming ham; Hants; Hon. Secretary; Mr. H. E. Haynes, Evesham ; Capt. F. Handley, London. (I) Dr. C. R. Illingworth, London; Inquirens (E) Mr. C. Kingzett, London; Mr. R. T. Kent, Glasgow ; Kertesz ; Dr. R. Kirk, Glasgow; Mr. G. T. Keele, London. (I) Messrs. A. Leney and Co., Dover; Mr. J. W. Lowe, Brighton; Messrs. Ledger Smith and Co., London; Mr. W. Lory, London; Rev. J. Lawrence, York Dr. J. F. Le Page, Manchester; H. W. Lyle, M.B., London; Mr. L. G. Lawson, Invergordon ; Mr. F. H. Lewis, Brighton. (M) M.R.C.S.Eng. Dr. G. Y. Mackay, Glasgow; Dr. N. J. McKie, Newton Stewart; Member ; Mr. C. A. Morton, Clifton ; Mr. J. C. P. Muir, London ; M.R.C.S., L.S.A.; Mr. W. Mackeith, London; Medicus; Mr. A. E. MacBride, Glasgow, (T) Mrs. L. F. Nash, London; T. E. Nichol, M.B., Margate J. M. Nicoll, M.B., Jarrow-on-Tyne. (O) One of the Profession in Doubt; Old Boy. (P) Dr. A. Paterson, Dundee; Miss N. Paul, London; Dr. H. Phillpotts, London; Dr. H. Page, Redditch ; Professor Penberthy, London. (a) Dr. D. Rosenau, Bad Kissingen; Mr. E. Robbins, London; Mr. E. D. Rowland, New Amsterdam; Messrs. Raphael Tuck and Sons, London; Mr. S. Regan, London; Mr. O. F Rowley, Barnsley; Mr. T. F. Raven, Broadstairs; Mr. D. B. Ross, Newtown ; Dr. J. J. Ridge, Enfield ; Mrs. Ralph-Hall, Buxton. (8) Dr. J. F. Sykes, London; Mr. F. A. Southam, Manchester ; Mrs. G. M. Sibley, London; Mr. H. Strachan, London ; Mr. C. T. Snedekor, London; Mr. G. W. Sidebotham, Hyde; Miss Sandwith, Haslemere; Dr. A. W. Sheen, Cardiff; Dr. E. M. Skerritt, Bristol; Dr. W. H. Sturge, Ivy bridge; Mr. A. Sutcliffe, Burnley; Mr. J. A. Storey, Dunstable. (Tr) T. M.; R. Thorburn, M.B., Sedbergh ; S. J. Taylor, M.B., Norwich ; Mr. C. B. Turner, Gt. Grimsby ; Dr. T. S. Toogood, London; Mr. B. Thornton, Margate. (V) Variola; Dr. Van Niessen, Wiesbaden; Mr. S. G. Vinter, Devonport; Mr. T. G. Verrall, Brighton. (W) Mr. W. R. Williams, Preston; Messrs. Williams and Norgate, London; W. P., M.B.; J. D. Wardale, M.B., Bridgwater; Mr. C. F. Wardley, Buxton; Dr. C. T. Williams, Iondon; Professor C. G. Wheeler, Iondon; Dr. A. E. Wright, Netley; Dr. J. F. Whittingdale, Sherborne; Dr. P. W. Williams, Clifton; Mr. W. B. Winckworth, London; J. Walters, M.B. Reigate; West London Medico-Chirurgical Society, Secretary, Lon don ; Mr. R. Willson, Oxford ; etc.

\section{BOOKS, ETC., RECEIVED.}

Lehrbuch der Nervenkrankheiten. Von Professor H. Oppenheim. London: Williams and Norgate. 1894. M. 20.

Gout and its Relations to Diseases of the Liver and Kidneys. By Dr. $R$. Roose. 7th Edition. London: $H . K$. Lewis. 1894.

Schnitte durch das erkrankte Rückenmark des Menschen. Von IDr. $P$. Kronthal. London: Williams and Norgate. 1894. 25s.

Textbook of Abdominal Surgery. By S. Keith, assisted by G. E. Keith Edinburgh and London: Young J. Pentland. 1894.

Zeit-und Streitfragen der Biologie. Von Dr. O. Hertwig. Heft I. Jena Gustav Fischer. 1894. M. 3.

International Clinics. Edited by Dr. J. Daland, Dr. J. M. Bruce, and Dr. D. W. Finlay. Vol. I. 4th Series. Philadelphia: J. B. Lippincott and Co. 1894 .

Handbuch der speciellen Therapie innerer Krankheiten. Funfte und Stintzing. Jena: Gustav Fischer. 1894 .

Festigkeit der menschlichen Gelenke. Von Dr. J. Fessler. Munchen Gustav Himmer. 1894 .

Einführung in das Studium der sozialen Hygiene. Von Dr. A. Nossig. Leipzig: Doutsche Verlags-Anstalt.

Pain; its Indications and Significance in the Domesticated Animals. By Professor Penberthy, F.R.C.V.S., National Veterinary Association. Birmingham: G. Jones and Son.

Stickland and Co.'s Improved Siok Room Chart. London: Stickland and $\mathrm{Co} .6 \mathrm{~d}$

Resoconto Clinico Triennale della Sezione Chirurgica dell 'Ospedaletto Infantile Regina Margherita in Torino per gli Anni, 1891-92-93.1 Per Tipografia Salestana. 1894.

** In forwarding books the publishers are requested to stite their selling prices. 